\title{
ALTERNATIVE OF MONETARY POLICY INDICATOR: PANEL DATA ANALYSIS FROM ISLAMIC BANKS IN MALAYSIA
}

\author{
Zuriyati Ahmad ${ }^{1}$ and Abdul Ghafar Ismail ${ }^{2}$ \\ ${ }^{1}$ Universiti Teknologi MARA Terengganu Department of Economics, Universiti Teknologi Mara, \\ 23000 Dungun Terengganu Malaysia. Email: zuriy271@tganu.uitm.edu.my \\ ${ }^{2}$ Professor of Banking and Financial Economics and Chairperson Organization of Islamic Economic \\ Studies and Thoughts Organization of Islamic Economic Studies and Thoughts, 43650 Bandar Baru \\ Bangi, Selangor Darul Ehsan, Malaysia. Email: agibab62@gmail.com
}

\begin{abstract}
The monetary policy indicators such as monetary aggregates, interest rates and Monetary Condition Index (MCI) are the traditional monetary policy indicators used in order to obtain early indication of the impact of monetary policy. These indicators could function as appropriate monetary policy indicators that will provide information to the monetary policy makers. The development in Islamic financial system however creates a challenge to find a monetary policy indicator, which is in conformity with Islamic teaching. Therefore, this paper is aimed to examine the future growth of nominal GDP as an alternative variable for monetary policy indicator in Islamic monetary system. The investigation will benefit from data of 17 Islamic banks in Malaysia which implement full fledge or Islamic windows scheme spanning from 2005 to 2010. GMM system method is used to analyze the data in hope to validate the appropriateness of the alternative monetary policy indicator. The result suggests that the future growth of nominal GDP is significant as monetary policy indicator and could be applied by the central bank in implementing the monetary policy especially in the dual banking system.
\end{abstract}

Keywords: Monetary Policy; Monetary Policy Indicators; Bank Financing. JEL Classification: E52; E58; C33; G21.

Received : September 30, 2018

Revised : October 20, 2018

Accepted : November 29, 2018 


\section{INTRODUCTION}

Central banks commonly monitor selected monetary policy indicator variables in order to obtain early indications of the impact of monetary policy. In this case, the variables that could function as appropriate monetary policy indicators will provide information to the monetary policy maker. With price stability, economic growth and unemployment rate as the goals of monetary policy, the monetary policy indicator chosen should be one that best contributes to achieving these goals.

Many studies (Bernanke and Blinder, 1992; Gerlach and Svensson, 2001; Nelson, 2002 and 2003; Fung and Yuan, 2010) explore this subjects but these are limited to conventional banks. These studies also highlight on the various methods applied to indicate the reliability and importance of each of the monetary policy indicators. They agree that the stock of money, interest rates and monetary condition index (MCI) are the common conventional monetary policy indicators which have been used in central banks world-wide.

With the development of the Islamic financial system there is a need for a relevant and simultaneously compatible indicators with the Islamic precepts of monetary policy. In fact, Oii (2008) highlighted the changes in Islamic financing where the asset structure are less sensitive to policy rate changes since a greater proportion of existing financing are not directly linked to changes in cost of fund. The establishment of Islamic banking creates a new system which might alter the framework of monetary policy. Thus, this study deviates from others in terms of applying an alternative monetary policy indicator in the Islamic banking system. Furthermore, in our concern there is no empirical study yet have been done.

The objective of this study is to suggest the alternative monetary policy indicator for Islamic monetary policy. It intends to empirically examine the alternative variable that can be used as monetary policy indicator. In this case, the future growth of nominal GDP is taken to be evaluated as an alternative monetary policy indicator in an Islamic monetary system.

The remaining of the paper is organized as follows. Section II outlines the commonly used monetary policy indicator. It is followed by the suggestion of the alternative monetary policy. Section II depicts the methodology under consideration and section III analyzes the empirical results. Lastly, section IV offer conclusions.

\section{LITERATURE REVIEW}

\subsection{Monetary Policy Indicators}

Basically money stock and interest rates are featured eminently as operational target and also as an indicator to assess monetary policy stance. An indicator is defined as some variable, which is influenced by monetary policy and gives early information on the likely outcomes for the final variable. A good indicator or information variable provides leading or contemporaneous information on the potential movements in policy objectives and it is normally not treated as an object to be controlled by central banks (Freedman, 1995).

Money stock was the traditional example of monetary policy indicator highlighted in the 1960s and 1970s. This indicator was supported by the Monetarists 
who claimed that money stock was the best way to signal monetary policy. The views of the Monetarist presented by Friedman and Shwartz (1963) analyzed the reaction of the stock of money exerted by important economic events in US. They found that the stock of money plays an important role in US economic. Another study which is interpreted as Monetarist, Sims (1972) demonstrated the causality between money supply and income. The study found money is significant in influencing the real output. Thus, it is concluded that money stock can be a good indicator for monetary policy. Other studies investigating the role of money as a monetary policy indicator were conducted by Coenen, Levin and Wieland (2001), Gerlach and Svensson (2001), Dortsey and Horstein (2003). Coenen et al. (2001) and Dortsey and Hornstein (2003) considered the information content of money. The information content of indicator variables were evaluated according to the extent that the monetary policy indicator would reduce the uncertainty surrounding the estimation problem faced by the policymaker and the market participants, and the extent to which the reduction in estimation uncertainty improves the policymaker's loss function. The information content provided by the monetary policy indicator variables is highly valuable, particularly to policymakers. Variables with high information content could function as the relevant variable in the implementation of macroeconomic policies.

While, Nelson (2002) and Nelson (2003) consider the information content in money by examining the model money demand specifications. This indicates that the money stocks respond to level of aggregate output and hence money has a potentially useful role as an indicator variable. The study concludes that money's role as a policy indicator depends on the stability of the money demand. This is among the deficiencies in using money stock as a monetary policy indicator. Later, the deficiencies have become widely recognized and consequently many researchers have tried to find alternative monetary policy indicators.

As opposed to the Monetarist, the Keynesian framework emphasizes on interest rate. They interpret the higher interest rates as a signal for tighter monetary policy and lower interest rates as a signal for easier monetary policy. Bernanke and Blinder (1992) for example applied the three-month Treasury bill rate, a tenyear government bond rate and a federal (fed) fund rates on different economic activities. The study used VAR methodology and concluded that the fed funds rate was the significant indicator to compare with other variables adopted since much of the information content of the economy is concentrated in it. This finding supports the adoption of the fed funds rate as a monetary policy indicator in US. Friedman and Kuttner (1992) on the hand had taken a commercial paper Treasury bill spread as an indicator of monetary policy. They monitored this indicator to assess whether they gain the desired effect. It is found that the wider spread indicated monetary tightening which leads to a decrease in business spending and subsequently real economic activity.

Bernanke and Mihov (1998) believe that there is no need to assume that a single variable is the best indicator of stance because price (inflation) can have two or more elements. The central banks can monitor more than one indicator at time. This was proved by Fung and Yuan (2010) who tested four different indicators that are significant in monetary policy stance. The indicator variables such as M1, the term spread, the overnight rate and the exchange rate were assumed to be a single 
indicator. Using the Bernanke and Mihov methodology, the result indicates that only the over-night policy rate was considered significant in providing information to monetary policy.

Subsequently, the researchers moved to another indicator to show the combination of multiple monetary policy indicators. It has been argued that, combining both interest and exchange rates in a single monetary policy indicator, a Monetary Conditions Index (MCI), may serve as a better indication of an overall policy stance (Freedman, 1995; Nadal De Simone; Hataisaree, 1998 and de Wet, 2002). Using the MCI which encompasses movements in both interest rates and exchange rates, may help monetary authorities to gain a better assessment of overall monetary conditions. Therefore, many central banks in industrialized countries such as the Bank of Canada (BoC), the Reserve Bank of New Zealand, the Central Banks of Norway, Sweden and Switzerland are among others to assess the effectiveness of monetary policy using MCI.

The MCI was particularly successful in Canada and in the Reserve Bank of New Zealand in the first half of the 1990s. Nevertheless, by the second half of the 1990s, monetary conditions were occasionally unsuccessful and caused conditions to move in unintended ways (Mayes and Riches, 1996). On the other hand, the MCI in the Norwegian and Swedish central banks have used their MCIs in a very limited way as indicators of monetary conditions when formulating monetary policy. It then does not show any significant adoption of this indicator in these countries.

\subsection{The Alternative Monetary Policy Indicator Using Future Information}

The alternative monetary policy indictor for Islamic monetary system was motivated by a research article in the Economist (2007). The research articles shows the gap between GDP growth and official interest rates for big economies such as Canada, China, the Euro area, India and Japan and found that there is no difference in movement pattern in interest rate and the nominal GDP growth. This indicates nominal GDP behave similarly to interest rate and able to become an indicator.

Following the Economist (2007), researchers such as Hanif and Shaikh (2010) take further effort to show that the average official interest rate and average nominal GDP growth rate moves along based on available data for Canada, 16 major Euro countries, Japan, the US and the UK for 1970-2008. Noreha and Radziah (2012) followed Hanif and Shaikh (2010) to the nominal GDP growth as monetary policy indicator in the case of Malaysia. Both studies propose the use of nominal GDP growth not only can be used as an information variable for the banking sector but also as a monetary policy instrument that encompass both the conventional and Islamic financial systems in central banks. The use of nominal growth of GDP should be able to signal the direction of economic performance. Besides that, the consideration of Mirakhor (2010) must be taken into account as he stated that the existing reference rate is "based on LIBOR, lending rate (BLR), and so on as "unknown" exogenously determined", and he urges to replace it with "something that is endogenous, i.e. certain as it is derived based on real data.". 
The nominal growth of GDP suggested by Economist (2007) Hanif and Shaikh (2010) and Noreha and Radziah (2012) is a potential mechanism that can be used as a monetary policy indicator. It is more comprehensive and reflects the real sector. The nominal growth of GDP works as a monetary policy indicator for Islamic finance products of asset side. Products on liabilities side can be priced upon the difference between nominal growth rate and the cost of deposit mobilization (Hanif and Shaikh, 2010).

Evaluation of the likely future state of GDP is also essential. The higher expected GDP indicates the higher expected profit. It will thus give higher returns to providers and higher cost to fund users. Fund providers will expect to contribute more funds and as there are more pool of funds the bank will increase the bank financing. This study therefore highlights the variable proposed by Hanif and Shaikh (2010) and Noreha and Radziah (2012). Nonetheless, it departs slightly from the previous studies by using the future growth of nominal GDP to capture future information and act as an alternative monetary policy indicator to be empirically tested.

\subsubsection{Model Specification}

The model developed for this study is based on Ehrman et al. (2001). Others such as Takada, Rocha and Nakena (2005); Zulkefly et al. (2011) and Sichei and Njenga (2012) also took the model as a benchmark study in bank lending to test for monetary policy indicator. Thus, the basic model for the loan demand $\left(\mathrm{L}^{\mathrm{d}}\right)$ and supply $\left(\mathrm{L}^{\mathrm{s}}\right)$ functions are written respectively as follows:

$$
\mathrm{L}_{\text {it }}^{\mathrm{d}}=\beta_{0}+\beta_{1} \mathrm{GDP}_{\mathrm{t}}+\beta_{2} \mathrm{INF}_{\mathrm{t}}+\beta_{3} \operatorname{Int}_{\mathrm{t}}+\varepsilon_{\mathrm{t}}
$$

while the loan supply equation will be:

$$
\mathrm{L}_{\mathrm{it}}^{\mathrm{s}}=\beta_{0}+\beta_{1} \mathrm{D}_{\mathrm{it}}+\beta_{2} \operatorname{Int}_{\mathrm{t}}+\beta_{3} \mathrm{MP}_{\mathrm{t}}+\varepsilon_{\mathrm{t}}
$$

In equation (1), bank $\mathrm{i}$ faces a loan demand $\left(\mathrm{L}^{\mathrm{d}}\right)$ that depends on economic performance/activity (GDP), inflation (INF) and the interest rate (Int). The quantity of loan demanded is a positive function of economic performance (GDP) and negatively function with interest rate (Int). While in equation (2) shows the loan supply by bank $\mathrm{i}\left(\mathrm{L}^{\mathrm{s}}\right)$ is a function of the available amount of deposits $(\mathrm{D})$, interest rate (Int) and monetary policy instrument (MP).

Plugging in all the determinants of loan supply and demand, the equilibrium condition in the lending market can be written as:

$$
\mathrm{L}_{\mathrm{i}}=\beta_{0}+\beta_{1} \mathrm{GDP}+\beta_{2} \mathrm{INF}+\beta_{3} \text { Int }+\beta_{4} \mathrm{D}+\beta_{5} \mathrm{MP}+\varepsilon_{\mathrm{t}}
$$

In this study however, some modifications have been done to suit the purpose of the study. The modifications have been constructed as follows: first, still referring to the conventional ideas formed above but the Islamic bank financing equation here employs macroeconomic variables and Islamic banking variables as these are the main characteristics of Islamic banking operation; and second, there are a few 
variables in Ehrman et al. (2001) that been omitted as they are not relevant to the purpose of the study and been replaced with more prominent variables for Islamic bank financing. For these reasons, equation (3) can be rewritten as follows:

$$
\mathrm{F}_{\mathrm{it}}=\beta_{0}+\beta_{1} \mathrm{GDP}+\beta_{2} \mathrm{D}+\beta_{3} \mathrm{MP}+\varepsilon_{\mathrm{t}}
$$

Thus, equation (4) indicates that $\mathrm{F}_{\mathrm{it}}$ the amount of financing in individual banks in period $t$ is depending on gross domestic product (GDP), the available amount of deposits (D) and the monetary policy indicators (MP).

GDP is taken as a dependent variable as it is the most direct measure to reflect performance in the economy. Economic conditions play a major role in determining Islamic bank financing in Malaysia. This was particularly true as the volume of Islamic bank financing was significantly affected by the financial turmoil caused by the Asian financial crisis of 1997 (Adebola et al., 2011). A stable GDP will form an expectation that the borrowers will be able pay back loans because of their ability to predict economic performance and possibly earn a good return on their investment projects. Islamic banks which have greater inter dependence and closer relationship with investment can adjust bank financing behaviour in response to signals from the GDP. Besides that, another reason for the inclusion of GDP is to control the demand side effects and the business cycles in the economy.

Islamic banks adjust their financing behavior in response to the signal of GDP factors, such that positive signals make banks more favourably disposed to financing and vice versa. Talavera et al. (2011), for example indicate that banks will give more loans during periods of boom and restrain lending when the economy is in recession.

The deposits in each bank are another factor which influences Islamic bank's willingness to supply financing. They are one of the resources available to the bank and a major source of bank financing. In other words, typically banks will rely solely on deposits as a source of funds which induces more financing supply sensitivity to monetary policy changes. Any additions or subtractions of deposits may influence future financing activities. In the case of Malaysia there are many studies analyzing the relevance of deposit and Islamic bank financing such as Raditya and Salina (2008), Rosylin et al. (2008), Salina et al. (2009) and Salina (2008). Most of these studies found that deposit are the relevant factor to the Islamic financing in Malaysia.

Monetary policy indicators which influence Islamic bank financing are the center of this study analysis. In line with previous literature the study used the typical monetary policy indicators such as interest rate, growth of money supply and the Monetary Condition Index (MCI) for comparison with alternative monetary policy indicators. Each of these monetary policy indicators has its own justification for being applied in this study. The first monetary policy indicator interest rates presented by interbank rates (KLIBOR) is used as it is strong indicator and move directly. It has been used as a benchmark in Islamic financial systems in Malaysia. The use of interest rates as one of the variables is also in line with most of the previous literatures in Malaysia such as Nor Azlan and Aisyah (2005), Fathin Faizah and Abdul Ghafar (2008), Raditya and Salina (2008) and Rosylin et al. (2008). This study tries to affirm the significance of interest rates as a monetary policy indicator especially in Islamic bank financing. 
The money supply which has been discussed in the literature has already lost its significance as a monetary policy indicator in Malaysia. Thus, this study tries to test the validity of the claims. Lastly, the MCI attempts to include MCI as a monetary policy indicator to test for its significant in the country. It has been found in Wai (2008) in Malaysia that augmented MCI follows the prediction of the GDP. Thus, for the study's comparison purposes it has been taken as one of the monetary policy indicators. The variable MCI has also been included in empirical testing of bank lending in European countries (de Bondt, 1998) and Switzerland (Bischel and Perez, 2005).

In order to capture for the future information, the future nominal GDP growth (FGDP) is included. As discussed earlier, this variable is the suggested monetary policy indicator. FGDP is calculated as the expected nominal GDP growth by one year $\left(\mathrm{GDP}_{\mathrm{t}+1}\right)$. It is also a direct measure to reflect performance in the economy. Thus, equation (4) will be rewritten as:

$$
\mathrm{F}_{\mathrm{it}}=\beta_{0}+\beta_{1} \mathrm{GDP}+\beta_{2} \mathrm{D}+\beta_{3} \mathrm{MP}+\beta_{4} \mathrm{FGDP}+\varepsilon_{\mathrm{t}}
$$

The study takes into account the effects of other potential factors influencing Islamic bank financing which is Bank Characteristic (BC). It also acts as a control variable. With bank characteristics involved the model is specified as:

$$
\mathrm{F}_{\mathrm{it}}=\beta_{0}+\beta_{1} \mathrm{GDP}+\beta_{2} \mathrm{D}+\beta_{3} \mathrm{MP}+\beta_{4} \mathrm{FGDP}+\mathrm{BC}+\varepsilon_{\mathrm{t}}
$$

The bank characteristics used in this study are bank's asset size (ASSET) and capital (CAP). Both bank characteristics are used as indicators for the bank to provide financing thus the equation is shown below:

$$
\mathrm{F}_{\text {it }}=\beta_{0}+\beta_{1} \mathrm{GDP}+\beta_{2} \mathrm{D}+\beta_{3} \mathrm{MP}+\beta_{4} \mathrm{FGDP}+\beta_{5} \mathrm{ASSET}+\beta_{6} \mathrm{CAP} \mathrm{it}_{\mathrm{it}}+\varepsilon_{\mathrm{t}}
$$

In equation (7), the volume of financing decided by an Islamic bank in a year is a function of its asset size. The asset size is measured by the bank's asset. Banks with larger assets tend to provide more financing than their smaller counterparts. This is due to the fact they have larger pools of funds and resources available.

Capitalization plays an important role which influence bank financing. Since Malaysia has to follow the regulatory capital ratio under the Basel Accord, the asset size of bank financing is a function of its capital base. As a consequence, a bank's capability to do the financing will be constrained. Despite the constraints in the bank financing, a bank's capital adequacy ratio can be a sign of capital strength. Hence, the capital strength in Islamic banks will be signified with the availability of providing the financing to its clients. The Islamic banking sector which has a higher capital will indicates strongly capitalized banks are able to provide more financing to businesses and create fund investment opportunities.

Eventhough asset size and capitalization were seen to be major bank specific characteristics that influence bank lending/financing in the literature, studies by Chimielewski (2006), Hou and Dickinson (2007) and Preatenue Podpiera (2007) argue that non performing loans have a significant impact over the loan supply function. Therefore, in capturing another bank characteristic of Islamic banks 
but using the past information, Non Performing Financing (NPF) is added as a variable. Equation (7) hence can be rewritten as follows.

$$
\begin{aligned}
\mathrm{F}_{\mathrm{i}}= & \beta_{0}+\beta_{1} \mathrm{GDP}+\beta_{2} \mathrm{D}+\beta_{3} \mathrm{MP}+\beta_{4} \mathrm{FGDP}+\beta_{5} \mathrm{ASSET}_{\mathrm{it}}+\beta_{6} \mathrm{CAP}_{\mathrm{it}}+\beta_{7} \mathrm{NPF}_{\mathrm{t}-1} \\
& +\varepsilon_{\mathrm{t}}
\end{aligned}
$$

This study used the lagged term of NPF as it represents the past information. This is because the amount of NPF is not normally known until the end of a period but financing decisions are always made at beginning of a period. It takes some times for NPF to exert its impact on bank financing and for banks to make the necessary adjustments. Consequently, Islamic banks make decisions according to their existing non performing financing situation. It can be roughly represented for example if there is a high level of NPFs, the willingness for their banks to expand financing is decreased.

\section{RESULTS AND FINDINGS}

The discussion of results obtained started with the selection of the lag length and the robustness of the results. Since the model is estimated using system GMM, in order to avoid the problem of creation of too many instruments due to a relatively small $\mathrm{N}$, the study has restricted instrument set. This is done by selecting the lag length following Roodman (2008) who practised techniques in limiting the number of lags such as using only certain lags instead of all available lags for instruments. This study thus only includes the contemporary values of the independent regressors and only one lag of the dependent variable. This was done for two reasons. First, the study works with an annual data set and therefore including more time lags seems not appropriate from an economic view of adjustment in the banking sector and second to get better specifications in a statistical sense in selecting the most the robust model.

The Sargan test in the model point out insignificant value which indicate it has good instruments and represent legitimate models. This test is higher than 0.10 that is statistically insignificant at the ten percent significance level. The null hypothesis should be accepted, hence providing evidence of the validity lags as instruments. The results of the specification test that is $\operatorname{AR}(2)$ for testing serial correlation are also valid. As shown in the table, the $p$ values for $A R(2)$ are higher than 0.10 . It implies that the value is statistically insignificant at the ten percent significance level. This indicates that the there is no serial correlation and the empirical model has been correctly specified. The Wald test has been estimated to show the significance of the models and overall it is significant.

In the general equation for bank financing, the results reveal that bank financing's first lag has a significant relationship with bank financing only in the first regression. The statistical value is 2.95 and it is statistically significant at a $1 \%$ significance level. It shows in the first regression that bank financing can be affected by past financing habits since the lagged of bank financing show the expected sign with a significant relationship. Nevertheless, the second and third regressions which included MCI and GM3 do not show a significant relationship. The banks are not depending on previous financing and do not judge the current 
situation and perform financing accordingly. The difference of the significance of the result might be influenced by differences of the monetary policy included which may have influence on each of the models.

Table 1.

Results of GMM Panel Data Estimation

\begin{tabular}{|c|c|c|c|c|c|c|}
\hline \multirow[t]{2}{*}{ Variables } & \multicolumn{2}{|c|}{$\begin{array}{c}1^{\text {st }} \text { Regression } \\
\text { (KLIBOR) }\end{array}$} & \multicolumn{2}{|c|}{$\begin{array}{l}2^{\text {nd }} \text { Regression } \\
\text { (GM3) }\end{array}$} & \multicolumn{2}{|c|}{$\begin{array}{l}3^{\text {rd }} \text { Regression } \\
\text { (MCI) }\end{array}$} \\
\hline & Coefficient & T Statistic & Coefficient & T statistic & Coefficient & T statistic \\
\hline $\mathrm{LF}(-1)$ & 0.0633 & $2.95^{* *}$ & 0.0372 & 0.8 & 0.0295 & 1.62 \\
\hline LGDP & -3.356 & $2.89^{* *}$ & -3.0181 & $2.73^{* *}$ & -4.4627 & $3.18^{* *}$ \\
\hline LFGDP & 2.4911 & 1.32 & 2.859 & $2.70^{* *}$ & 4.3278 & $3.10^{* *}$ \\
\hline LD & 0.8048 & $33.44^{* *}$ & 0.8011 & $28.41^{* *}$ & 0.7863 & $28.29^{* *}$ \\
\hline LNPF(-1) & 0.011 & 1.02 & 0.011 & 0.95 & 0.0272 & 1.78 \\
\hline LASSET & 0.2 & $6.14^{* *}$ & 0.21 & $6.19^{* *}$ & 0.2254 & $6.16^{* *}$ \\
\hline LCAP & 0.1587 & $2.14^{*}$ & 0.1527 & $2.09^{*}$ & 0.1754 & $1.97^{*}$ \\
\hline KLIBOR & 0.059 & 0.52 & & & & \\
\hline GM3 & & & 0.0003 & 0.49 & & \\
\hline $\mathrm{MCI}$ & & & & & -0.4771 & 1.86 \\
\hline \multicolumn{7}{|c|}{ Diagnostic Statistics } \\
\hline No of Obs & \multicolumn{2}{|c|}{85} & \multicolumn{2}{|c|}{85} & \multicolumn{2}{|c|}{85} \\
\hline Wald Chi2 & \multicolumn{2}{|c|}{2599398.67} & \multicolumn{2}{|c|}{151971.67} & \multicolumn{2}{|c|}{54728.04} \\
\hline Prob Chi2 & \multicolumn{2}{|c|}{0} & \multicolumn{2}{|c|}{0} & \multicolumn{2}{|c|}{0} \\
\hline $\operatorname{AR}(2)$ & \multicolumn{2}{|c|}{0.0981 (0.9219) } & \multicolumn{2}{|c|}{$0.0876(0.9320)$} & \multicolumn{2}{|c|}{$0.1205(0.9041)$} \\
\hline Sargan statistics & \multicolumn{2}{|c|}{7.3366 (0.3947) } & \multicolumn{2}{|c|}{7.5070 (0.9302) } & \multicolumn{2}{|c|}{$6.2109(0.5154)$} \\
\hline
\end{tabular}

The macroeconomic variable of real GDP performs well in explaining bank financing. The GDP in all estimates are significant. All the coefficients have negative signs, which is contrary to what is normally expected. The negative sign of the GDP variable is mainly related to bank financing with its dynamics. Bank financing has a relatively has rich variation and the basic model with only one lag of the dependent variable fails to correctly capture it. Thus, this will lead to a negative association between the GDP and bank financing variables. Nevertheless, the results obtained are similar to other studies such in France and Spain Ehrman et al. (2001), South Africa (Sichei, 2005), Slovenia and Hungary (Matousek and Sarantis, 2009) and also in Malaysia (Fathin Faizah and Abdul Ghafar, 2008; Zulkefly et al., 2011) which GDP enters in with a negative sign. In contrast, another study in Malaysia, Adebola et al. (2011) obtained a positive sign but had an insignificant relationship.

Contrarily to the GDP, the future growth of nominal GDP shows expected signs in all three models. Two out of three regressions also have highly significant relationships with bank financing. The second and third regressions have the statistical values of 3.08 and 4.46 respectively. Both show that they are statistically significant at a $1 \%$ significance level. Therefore, the future growth of nominal GDP which carries the future information and acts as a monetary policy indicator is 
able to signal the direction of expected economic performance to influence bank financing. It provides empirical evidence to the monetary policy indicator GDP growth proposed by Hanif and Shaikh (2010) for bank financing.

Deposits are one of the major sources of funding in financing. They are supposed to have a positive relationship. The findings related to deposits show it has the expected sign in all three equations that are significant at a $1 \%$ significance level. The significant value of each regression shows 33.44, 28.41 and 28.29 respectively. These are consistent with the previous findings in Malaysia such as Raditya and Salina (2008), Rosylin et al. (2008), Salina et al. (2009) and Salina (2008). The significant of this variable reveals that the deposit consisting of the total of mudharabah and non mudharabah are able to increase the Islamic bank financings. Thus, Islamic banks are also contributing as the providers of financing for households or firms in Malaysia.

The estimates from three model specifications in respect to the monetary policy indicator show none of the monetary policy indicators are statistically significant. It indicates that all the monetary policy indicators are poor indicators in explaining behavior of bank financing. The result for example of interbank rates is surprisingly contrary to the belief of prior expectations. The finding does not show interbank rate will lead interest rate to be useful as an indicator of monetary policy in Malaysia. It shows just a very weak relationship which is contrary to the finding of Zulkefly et al. (2011) that bank loan supply is negatively and significantly influenced by interest rate in Malaysia. The result also shows the finding is positive and not as expected which is an inverse relationship between bank's financing and interest rates.

The growth in money supply (GM3) also does not have statistically significant effects on bank financing even though it produces the expected sign. The results illustrate that if central banks expand or increase the money supply into the system, this increases the Islamic bank financing. Even though it is not significant the sign is similar to the results of Juurikalla (2011) but contrary with the result obtained by Fathin Faizah and Abdul Ghafar (2008) in the case of Malaysia and Somoye and Ilo (2009) in the case of Nigeria. Lastly, the result of MCI has the expected sign but unfortunately does not help to explain the estimation of bank financing. This oppose to the highly significant result obtained by de Bondt (1998) in France and Italy and Bischel and Perrez (2005) in Switzerland.

Based on these result, no significant monetary policy indicator effects on bank financing could be found. The lack of relationship between monetary policy indicators and bank financing may be due to reasons why the monetary policy indicator effects on bank financing may be neutralized by some other effects. Thus, it will not be an effective monetary policy indicator. Nevertheless, as earlier stated bank financing decisions may be responsive to other specific factors such as banks specific factor. For example, the results obtained in this study are similar to the study done in Russia by Juurikalla et al. (2011) and Vinhas de Souza (2006) who concluded that the effects of monetary policy indicators are linked to the bank capitalization and assets.

The lagged NPF enters insignificantly in all specification models with the unexpected signs. The positive sign show that Islamic banks will increase their bank financing at greater level of lagged NPF. This finding is similar to the case of 
Republic of Czech (Pretenue Podpiera, 2007) positive sign but in contrast it shows that the lagged NPF is not an important variable to bank lending.

Related to bank specific characteristics, asset size and Capital Adequacy Ratio (CAR) usually are the most influential factors over the bank financing or bank lending. For example, Ehrman's (2001) study in Euro area shows that bank asset size is highly significant and shows the expected signs. The bigger the volume of bank asset means the bank can provide more funding to bank financing.

Capitalization (CAP) represented by the Capital Adequacy Ratio (CAR) is also consistent with the previous findings which is significant. The results show both of the variables are significant at $1 \%$ and $5 \%$ levels of significance in all three models. The statistically significant coefficient of variable assets and capital in the models indicates the crucial role of bank specific factors in bank financing decisions. The estimation results are consistent with Kishan and Opiela (2000) and Gambarcota and Mistrulli (2004). They show that banks with higher CARs are more likely to experience an increase in bank financing. This may be consistent with the fact that CAR provides a sufficient buffer and bank financing is more secured when CAR increases.

\section{CONCLUSION}

The objective of this study was to test the alternative variable that can be used as monetary policy indicator in Islamic monetary system. This has been done by evaluating the future growth of nominal GDP as an alternative monetary policy indicator in Islamic monetary system. As obtained by the results, none of the monetary policy indicators which are commonly applied are shown to be important in Malaysia. In fact, the usually considered important monetary policy indicator in Malaysia the interest rate does not show any signs of importance in the result. $\mathrm{MCI}$ also does not prove any significance. Lastly the growth of money supply as found by other researchers has definitely lost its significant as a monetary policy indicator. On the other hand, the future growth of nominal GDP as an alternative monetary policy shows potential to be a monetary policy indicator in the Islamic financial system. In this case, the future growth of nominal GDP is able to signal the direction of expected economic performance and substantially influencing bank financing. Besides that the future growth of nominal GDP can be an acceptable solution to benchmarking in the presence of real economic activity.

\section{REFERENCES}

Adebola, S.S., Wan Sulaiman, W. Yussof., \& Dahalan, J. (2011). The Impact of Macroeconomics Variables on Islamic Banks Financing in Malaysia. Research Journal of Finance and Accounting, 2, 22-32.

Amidu, M. (2006). The Link between Monetary Policy and Bank Lending Behaviour: The Ghanaian Case. Bank and Bank Systems, 1(4), 38-48.

Bernanke, B.S., \& Blinder, A.S. (1992). The Federal Funds Rate and the Channels of Monetary Transmission. American Economic Review, 82(4), 901-921.

Bernanke, B.S., \& Mihov, I. (1998). Measuring Monetary Policy. The Quarterly Journal of Economics, 113(3), 869-902. 
Bischel, R., \& Perrez, J. (2005). In Quest of the Bank Lending Channel: Evidence for Switzerland Using Individual Bank Data. Swiss Journal of Economic and Statistics, 141, 165-190.

Brismiss, S. N., Kamberogiou, N.C., \& Simigiannis, G.T. (2003). Is There a Bank Lending Channel in Greece? Evidence from Bank Level Data. In Angeloni et al. Monetary Transmission Mechanism in the Euro Area. United Kingdom. Cambridge: University Press.

Chmielewski, T. (2006). Bank Risk, Risk Preference and Lending. MPRA Paper 5131. http://mpra.ub.uni-muenchen.de/5131/1 /MPRA_paper_5131.pdf [25 July 2011].

Coenen, G., Levin, A., \& Wieland, V. (2001). Data Uncertainty and the Role of Money as an Information Variable for Monetary Policy. European Central Bank Working Paper Series 084, European Central Bank.

de Bondt, G. (1998). Credit Channels in Europe: Bank Level Data Analyses. Research Memorandum WO\&E, 543/9813, de Nederlandsche Bank, Amsterdam.

de Haan, L. (2003). The Impact of Monetary Policy on Bank Lending in the Netherlands. In Angeloni, A. et al. Monetary Policy Transmission in the Euro Area. United Kingdom: Cambridge University Press.

Dortsey, M., \& Horstein, A. (2003). Should a Monetary Policymaker Look at Money?. Journal of Monetary Economics, 50(3): 547-579.

Driscoll, J. C. (2004). Does Bank Lending Affect Output? Evidence from the U. States. Journal of Monetary Economics, 51(3), 451-471.

Economist. (2007). Closing the Valve. The Economist, London, Print Edition, June 14.

Ehrmann, M., Gambacorta, L., \& Sevestre, P. (2001). Financial System and the Role of Banks in Monetary Policy Transmission in the Euro Area. European Central Bank Working Paper, No.105/2001, European Central Bank.

Fathin, F. Said., \& Abdul Ghafar, Ismail. (2007). How Does the Changes in Monetary Policy Affect Lending Behaviour of Islamic Banking in Malaysia?. Jurnal Ekonomi Pembangunan, 12(23), 163-177.

Freedman, C. (1995). The Role of Monetary Condition Index and the Monetary Condition Index in the Conduct of Policy. Bank of Canada Review, Autumn: 5359.

Friedman, B.M., \& Schwartz, A.J. (1963). A Monetary History of the United States, 1867-1960. Princeton: Princeton University Press.

Friedman, B.M., \& Kuttner, K.N. (1992). Money, Income, Prices and Interest Rates. American Economic Review, 82, 472-492.

Fung, B.S.C., \& Yuen, M. (2010). Measuring the Monetary Policy Stance of Monetary Policy. http://publications.gc.ca/collections/Collection/FB2-15-1999E-6.pdf. [26 November 2011]

Gerlach, S., \& Svensson, L.O.E. (2003). Money and Inflation in the Euro Area: A Case for Monetary Indicators?. Journal of Monetary Economics, 50, 1649-1972.

Hanif M. N., \& Sheikh, S. (2009). Central Banking and Monetary Management in Islamic Financial Environment. MPRA Paper No. 23548. http://mpra.ub.unimuenchen.de/23548 [27 July 2012]. 
Hataisaree, R. (2000). The Role of Monetary Conditions and Monetary Conditions Index in the Conduct of Monetary Policy: The Case of Thailand under the Floating Rate Regime. The Bank of Thailand.

Holtemellor, O. (2003). Money Stock, Monetary Base and Bank Behaviour in Germany. Jahrbucher National Okoronomies and Statistik, 223, 257-278.

Hou, Y., \& Dickinson, D. (2007). The Non Performing Loans: Some Bank and Evidence. Research Conference on Safety and Efficiency of the Financial System, August. http://cba.upd.edu.ph/asialink /Hou_Dickinson.pdf [12 January 2011].

Juurikalla, T., Karas, A., \& Solanko, L. (2011). The Role of Banks in Monetary Transmission Mechanism: Empirical Evidence from Russia. Review of International Economics, 19(1), 109-121.

King, M.A. (2004). No Money, No Inflation - The Role of Money in the Economy. Bank of England Quarterly Bulletin, Summer, 162-177.

Kishan, R.P., and Opiela, T.P. (2000). Bank Size, Bank Capital and Bank Lending Channel. Journal of Money, Credit and Banking, 2, 121-141.

Matousek, R., \& Sarantis, N. (2009). The Bank Lending Channel and Monetary Transmission in Eastern and European Countries. Journal of Comparative Economics, 37(2), 321-334.

Mayes, D., \& Riches B. 1996. The Effectiveness of Monetary Policy in New Zealand. Reserve Bank of New Zealand Bulletin, No. 59, Reserve Bank of New Zealand.

Nadal De Simone, F., Richard, D., \& Redward, P. (1996). A Monetary Condition Index for New Zealand. Reserve Bank of New Zealand Discussion Paper 96/2, Reserve Bank of New Zealand.

Nelson. E. 2002. Direct Effects of Base Money on Aggregate Demand: Theory and Evidence. Journal of Monetary Economics, 49, 687-708.

Nelson, E. (2003). The Future of Monetary Aggregates in Monetary Policy Analysis. Journal of Monetary Economics, 50, 1029-59.

Noreha, Halid., \& Radziah, Latif. (2012). Developing Reference Rate of Return Based on Real Sector Economy: A Case of Malaysia. African Journal of Business Management, 8, 2871-2877.

Nor Azlan, Ghazali., \& Aisyah, Abdul Rahman. (2005). The Transmission Mechanism of Monetary Policy: Through Bank Loans or Deposits? IIUM Journal of Economics and Management, 13(1), 1-18.

Ooi, S. K. (2008). The Monetary Transmission Mechanism in Malaysia: Current Development and Issue in Transmission Mechanisms for Monetary Policy in Emerging Market Economies. BIS Papers No. 35, Bank for International Settlements.

Prutenue Podpiera, A. (2007). The Role of Banks in Czech Monetary Policy Transmission Mechanism. Economic of Transition, 15(2), 393-428.

Raditya, Sukmana., \& Salina, H. Kassim. (2010). Roles of the Islamic Banks in the Monetary Transmission Process in Malaysia. International Journal of Islamic and Middle Eastern Finance and Management, 3(1), 7-19.

Roodman, D.M. (2008). A Note on the Theme of Too Many Instruments. Centre the Global Development Working Paper, No. 125. 
Rosylin, M. Yusof., Mohamed A. W., \& M. Shabri, A. Majid. (2009). Monetary Policy Shocks and Islamic Banks Deposit in Dual Banking System: Empirical Evidence from Malaysia and Bahrain. A Comparative Analysis between Malaysia and Bahrain. $8^{\text {th }}$ Global Conference Business and Economics, Florence, Italy $18^{\text {th }}$ $19^{\text {th }}$ October.

Salina, H. Kassim. (2008). The Role of Bank Lending in the Monetary Transmission Process of a Developing Economy: Evidence from Malaysia. Saving and Development, 33 (4), 301-319.

Salina, H. Kassim., \& Turkhan Ali, A. Manap. (2008). The Information Content of the Islamic Interbank Money Market Rate in Malaysia. International Journal of Islamic and Middle Eastern Finance and Management, 1(4), 304-312.

Salina, H. Kassim., M. Shabri, A. Majid., \& Rosylin, M. Yusof. (2009). Impact of Monetary Policy Shocks on the Conventional and Islamic Banks in a Dual Banking System: Evidence from Malaysia. Journal of Economic Cooperation and Development, 30(1), 41-58.

Sichei, M.M. (2005). Bank Lending Channel in South Africa: Bank Level Dynamic Panel Data Analysis. Working Paper University of Pretoria, No. 5, University of Pretoria.

Sichei, M.M., \& Njenga, G. (2012). Does Bank Lending Channel Exist in Kenya? Bank Level Panel Data Analysis. International Research Journal of Finance and Economics, 84, 25-32.

Sims, C.A. (1972). Money, Income and Causality. The American Economic Review, 62(4), 540-552.

Somoye, R.O.C., \& Ilo, B.M. (2009). The Impact of Microeconomic Instability on the Banking Sector Lending Behaviour. Journal of Money, Investment and Banking, 7, 29-42.

Takada, T., Rocha, F., \& Nakena, M. (2005). The Reaction of Bank Lending to Monetary Policy in Brazil. Revista Brassileira de Economia, 59, 107-126.

Talavera, O., Tsapin, A., and Zhoulud, O. (2012). Macroeconomic Uncertainty and Bank Lending: The Case of Ukraine. Economic Systems, 36(2), 279-293.

Wai, C. P. (2010). Augmented MCI: An Indicator of Monetary Policy for Asean 5 ? Discussion Paper, 25(10), University of Monash.

Zulkefly, A. Karim., Wan Ngah., Wan A. S., \& Bakri, A. Karim. (2011). Bank Lending Channel of Monetary Policy: Dynamic Panel Data Study of Malaysia. Journal of Asia Pacific Business, 12, 225-243. 